\title{
Version 8 SBUV Ozone Profile Trends Compared with Trends from a Zonally Averaged Chemical Model
}

Joan E. Rosenfield

Goddard Earth Science and Technology Center, University of Maryland Baltimore County, Baltimore Maryland, USA

Stacey Frith

Science Systems and Applications Inc., Lanham, MD, USA

Richard Stolarski

Atmospheric Chemistry and Dynamics Branch, NASA Goddard Space Flight Center, Greenbelt, MD, USA 


\begin{abstract}
Linear regression trends for the years 1979-2003 were computed using the new Version 8 merged Solar Backscatter Ultraviolet (SBUV) data set of ozone profiles. These trends were compared to trends computed using ozone profiles from the Goddard Space Flight Center (GSFC) zonally averaged coupled model. Observed and modeled annual trends between $50^{\circ} \mathrm{N}$ and $50^{\circ} \mathrm{S}$ were a maximum in the higher latitudes of the upper stratosphere, with southern hemisphere $(\mathrm{SH})$ trends greater than northern hemisphere $(\mathrm{NH})$ trends. The observed upper stratospheric maximum annual trend is $-5.5 \pm 0.9 \% /$ decade $(1 \sigma)$ at $47.5^{\circ} \mathrm{S}$ and $-3.8 \pm 0.5 \% / \mathrm{decade}$ at $47.5^{\circ} \mathrm{N}$, to be compared with the modeled trends of $-4.5 \pm 0.3 \% / \mathrm{decade}$ in the $\mathrm{SH}$ and $-4.0 \pm 0.2 \% /$ decade in the NH. Both observed and modeled trends are most negative in winter and least negative in summer, although the modeled seasonal difference is less than observed. Model trends are shown to be greatest in winter due to a repartitioning of chlorine species and the increasing abundance of chlorine with time. The model results show that trend differences can occur depending on whether ozone profiles are in mixing ratio or number density coordinates, and on whether they are recorded on pressure or altitude levels.
\end{abstract}




\section{Introduction}

Stratospheric ozone profile measurements have been made by the Solar Backscatter Ultraviolet instruments (SBUV and SBUV/2) since November 1978. Hood et al. [1993] estimated ozone trends using Nimbus 7 SBUV data for the period November 1978 to June 1990 . They found maximum upper stratospheric annual trends, poleward of $50^{\circ}$, of $\sim 8 \%$ /decade in the northern hemisphere $(\mathrm{NH})$ and $\sim 12 \% /$ decade in the southern hemisphere $(\mathrm{SH})$. Depletions increased with increasing latitude in both hemispheres. They reported maximum upper stratospheric high latitude negative trends in the late fall and early winter seasons.

Hollandsworth et al. [1995] combined reprocessed Nimbus 7 SBUV ozone data with observations from the SBUV/2 instrument on NOAA 11, and computed updated profile trends for the period November 1978 through June 1994. They found a general pattern of ozone loss similar to that computed by Hood et al. [1993], but obtained smaller negative trends with the additional data. Maximum high latitude upper stratospheric trends were $\sim-8 \%$ decade in the $\mathrm{NH}$ and $\sim-10 \% / d e c a d e$ in the SH. They also reported maximum high latitude upper stratospheric negative trends in the late fall and early winter.

A large group of research scientists [WMO, 1998; Randel et al., 1999; Newchurch et al., 2000; Cunnold et al., 2000] reevaluated the vertical distribution of ozone trends for the period 1979 to 1996, including trends from the SBUV and the Stratospheric Gas and Aerosol Experiment

(SAGE) instruments. They confirmed the previously reported latitudinal structure of trends; i.e. a maximum negative trend in the extra tropics and a minimum negative trend in the tropics, with a minimum downward trend at all latitudes at $\sim 30 \mathrm{hPa}$. They concluded that SAGE trends were more negative than SBUV trends at nearly all latitudes. In the mid-latitudes maximum upper 
stratospheric trends were $-9 \%$ decade for SAGE and $-5 \% /$ decade for SBUV. They found that aithough SBUV upper stratospheric anmual trends were nore negative in the SH than the NH, this difference was not statistically significant. SAGE annual trends were shown to have no interhemispheric difference. They also observed that upper stratospheric trends were most negative in the winter season for both SBUV and SAGE. They found maximum upper stratospheric downward annual trends over $40^{\circ}-50^{\circ} \mathrm{N}$ to be $\sim-5 \% /$ decade for SBUV.

It has been established that negative trends in ozone have arisen from the increasing amounts of anthropogenic chlorofluorocarbons (CFCs) in the stratosphere. The general pattern of the observed latitudinal and vertical dependence of ozone profile trends is in accord with theoretical calculations using chemical models [e.g., Chandra et al., 1995; Jackman et al., 1996; Considine et al., 1998]. In the upper stratosphere ozone chemistry is dominated by gas-phase reactions, and the latitudinal dependence is understood to arise from the increase of active chlorine with latitude due to the observed decrease of methane with latitude [Solomon, 1999]. Recently, vertical profiles of SAGE ozone annual trends over the period 1980-2000 were compared with eight zonally averaged chemical models for northern and southern mid-latitudes [WMO, 2003]. While the observed shape of the profile was well reproduced by all the models, there was a large variation in the calculated maximum negative trends. Those models that were interactive in temperature underestimated the 40-50 km downward trends, while the non-interactive models tended to overestimate the downward trends in this region.

Considine et al. [1998] sought to explain the observation of Hood et al. [1993] that SBUV annual SH trends were more negative than NH trends at $1 \mathrm{hPa}$ and latitudes greater than $60^{\circ}$. They found that, in the Goddard Space Flight Center (GSFC) zonally symmetric interactive chemical model, the computed high latitude trend asymmetry was mainly due to 
interhemispheric differences in chlorine partitioning caused primarily by lower amounts of $\mathrm{CH}_{4}$ and $\mathrm{NO}$ in the SH than the NH. However, they did not find that 1992-94 observations of ClO and $\mathrm{CH}_{4}$ from the Upper Atmosphere Research Satellite (UARS) showed the required interhemispheric asymmetries.

Li et al. [2002] used a chemical box model constrained by UARS temperatures and constituents to evaluate ozone trends at $45^{\circ}$ latitude and $43 \mathrm{~km}$ for the two periods 1979-1996 and 1985-1996. They computed the largest negative trends in winter, which they attributed to larger $\mathrm{ClO}$ in winter, as well as an increasing contribution with time of the ozone loss due to the chlorine catalytic cycle and a smaller contribution due to $\mathrm{O}+\mathrm{O}_{3}$ cycle. They found larger computed downward trends in the SH than the $\mathrm{NH}$ which they attributed to temperature and methane asymmetries.

Very recently, the newly reprocessed Version 8 SBUV combined data set $[R$. McPeters, $L$. Flynn, private communication] has become available. The data are from the SBUV instrument on the Nimbus-7 satellite and the SBUV/2 instruments on the NOAA-11, NOAA-16, and NOAA-9 satellites, giving a complete time series between 1979 and 2003. The Version 8 reprocessing of the SBUV data included a reexamination of the calibration histories of each instrument. The data from all instruments have now been adjusted to a common reference, and the data can be merged into a continuous data set without further changes. The SBUV data and details of the data set construction are available at http:/hyperion.gsfc.nasa.gov/Data_services/merged/index.html.

In this paper we compare ozone profile trends computed with this new Version 8 SBUV data set with trends modeled by the GSFC interactive zonally averaged model. This model has been used to study the impact of the Mount Pinatubo aerosol on stratospheric species [Rosenfield et 
al., 1997; Considine et al., 2001] and to predict future changes in global stratospheric ozone [Rosenfieid et ai., 2002; Rosenfield, 2003]. We focus mainly on the upper stratospherc, and examine both annual and seasonal trends. We find that, with the longer UARS data set than was available to Considine et al. [1998], we are able to account for interhemispheric and seasonal differences in computed ozone profile trends.

\section{Method}

Linear regression trends for the period January 1979 - December 2003 were computed using the Version 8 SBUV vertical ozone profiles and ozone profile output from the GSFC zonally averaged interactive chemical model. The SBUV data set provides profiles of ozone layer amounts and mixing ratios as a function of pressure. We have used the mixing ratios, which are given at the following pressure levels; $0.5,0.7,1.0,1.5,2.0,3.0,4.0,5.0,7.0,10.0,15.0,20.0$, $30.0,40.0$, and $50.0 \mathrm{hPa}$. The data were monthly and zonally averaged, and periods of missing data were filled in by linear interpolation. The data are reported at five degree latitude intervals, between $87.5^{\circ} \mathrm{S}$ and $\mathrm{N}$. The NOAA-9 $\mathrm{pm}$ observations were not used in this study due to problems with the data quality. We show trends only between the latitudes $50^{\circ} \mathrm{S}$ to $50^{\circ} \mathrm{N}$. Trends at higher latitudes are suspect due to the large amount of missing data, especially in the southern hemisphere. Although results will be shown for both the upper and lower stratosphere in the $50^{\circ} \mathrm{S}$ to $50^{\circ} \mathrm{N}$ latitude range, the main focus will be on upper stratospheric trends in the middle latitudes.

The chemical model used is the GSFC chemistry-radiation-dynamics interactive 2-D (latitudepressure) model. The model has been described by Rosenfield [2003] and Rosenfield et al. [2002]. Gas phase reaction rates and photolysis cross sections are from Sander et al. [2003]. A time dependent run between 1969 and 2003 was carried out, using the natural and anthropogenic 
source gas boundary conditions given by Scenario A3 of $W M O[1999, \mathrm{p} .12 .7]$. The period between 1969 and 1979 aliowed for model spinup. Süface chlorine loadings were 2.26 ppbv in 1979 , increasing to $3.59 \mathrm{ppbv}$ in 1995 , and declining to $3.49 \mathrm{ppbv}$ in 2003 . Between 1979 and 2003 surface methane increased from $1.56 \mathrm{ppmv}$ to $1.77 \mathrm{ppmv}$, nitrous oxide from $301 \mathrm{ppbv}$ to $323 \mathrm{ppbv}$, and carbon dioxide from $336 \mathrm{ppmv}$ to $378 \mathrm{ppmv}$. An additional run was carried out in which carbon dioxide amounts were fixed at 1979 values in order to examine the effect that the greenhouse cooling of the stratosphere would have on ozone trends. The monthly and zonally averaged computed ozone profile mixing ratios were interpolated to the SBUV latitudes and pressure levels.

A standard multiple linear regression statistical model was used to compute the annual mean and seasonal trends of the SBUV and modeled ozone between 1979 and 2003 . The trend model as applied to the SBUV data included 11-year solar cycle, quasi-biennial oscillation (QBO), seasonal, and trend terms. The solar and QBO terms were omitted when computing the 2D model trends, as the model runs did not include solar cycle or QBO variations. Statistical errors were modeled using a first order autoregressive process. Instrument errors were not taken into account in this study.

\section{Annual Mean Trends}

Latitude-pressure sections of the annual mean SBUV ozone trends are shown in Figure 1. There are local maxima of negative trend values in the upper stratosphere higher latitudes at 2-3 $\mathrm{hPa}$ and in the lower stratosphere higher latitudes at $50 \mathrm{hPa}$, with minima near 10-30 $\mathrm{hPa}$. This pattern agrees with results previously obtained for ozone trends [WMO, 1998; WMO, 1999]. Latitude-pressure sections of the 2D model annual mean trends, shown in Figure 2, exhibit the same general features as the observed trends. Table 1 shows the maximum annual mean upper 
stratospheric trends at $47.5^{\circ}$ latitude for both the SBUV data and the $2 \mathrm{D}$ model. The errors indicated are the $1 \sigma$ statistical uncertainties. In the upper stratosphere the SII trends are more negative than the NH trends, for both data and model. The 2D model trends, however, exhibit less interhemispheric asymmetry than do the observed trends. The maximum $2 \mathrm{D}$ model NH trend of $-4.0 \pm 0.2 \% /$ decade at $2-3 \mathrm{hPa}$ agrees very well with the $-3.8 \pm 0.5 \% /$ decade trend computed for SBUV. In the SH the agreement is less good, although well within the 20 uncertainties. The model maximum trend is $-4.5 \pm 0.3 \% /$ decade at $2 \mathrm{hPa}$ compared to the SBUV trend of $-5.5 \pm 0.9 \% /$ decade. In the tropical upper stratosphere, the modeled trends are more negative than the observed trends.

Negative trends are a minimum in the $\sim 10-30 \mathrm{hPa}$ region at all latitudes. Secondary maxima in the computed trends occur in the lower stratosphere at $47.5^{\circ}$ latitude. In the $\mathrm{NH}$ the $2 \mathrm{D}$ model trend of $-1.8 \pm 0.2 \%$ decade agrees well with the SBUV trend of $-2.2 \pm 0.5 \% /$ decade. In the $\mathrm{SH}$, however, the model trend of $-3.8 \pm 0.6 \% /$ decade is quite a bit larger than the $-2.9 \pm 0.7$ \%/decade trend computed for SBUV. It should be kept in mind that the observations are smeared in the vertical, with a resolution of $\sim 6 \mathrm{~km}$ at $2-3 \mathrm{hPa}$ degrading to $\sim 10 \mathrm{~km}$ at $20 \mathrm{hPa}$ and below. In contrast, the vertical resolution of the $2 \mathrm{D}$ model is $\sim 2 \mathrm{~km}$ throughout the stratosphere.

Figure 3 shows latitude-pressure sections of the 2D model annual mean trends for the case when the model $\mathrm{CO}_{2}$ is fixed at 1979 values. Throughout the upper stratosphere, where carbon dioxide cooling is greatest, the computed ozone trends are more negative than is the case for increasing $\mathrm{CO}_{2}$. The maximum upper stratospheric trends are given in Table 1. As was shown in Rosenfield et al. [2002], the stratospheric cooling due to increasing $\mathrm{CO}_{2}$ results in a slowing of the ozone catalytic loss cycles, thus reducing the downward trend. 
Figure 4 shows vertical profiles of the observed and modeled annual mean trends (case of increasing carbon dioxide) for the mid-latitude bands $30^{\circ}-50^{\circ} \mathrm{N}$ and $\mathrm{S}$. The agreement between the modeled and observed trends is quite good in the $\mathrm{NH}$ between 1 and $10 \mathrm{hPa}$. Maximum $\mathrm{NH}$ upper stratospheric trends are $-3.4 \pm 0.6 \% /$ decade and $-3.6 \pm 0.2 \% /$ decade for SBUV and 2D model, respectively. In the SH the agreement in the upper stratosphere is less good, but still well within $2 \sigma$ uncertainties, with the maximum $2 \mathrm{D}$ model trend of $-3.8 \pm 0.3 \% /$ decade less negative than the maximum SBUV trend of $-4.6 \pm 0.6 \% /$ decade. For both model and SBUV, the SH negative trend is larger than in the $\mathrm{NH}$, with the $2 \mathrm{D}$ model result having a smaller hemispheric difference. The difference between the SBUV NH and SH trends is not, however, statistically significant.

Below $10 \mathrm{hPa}$, the model trend agrees well with the data in the $\mathrm{SH}$, in contrast to the $\mathrm{NH}$, where the agreement is poor. In the lower stratosphere dynamics plays a large role in determining the ozone distribution, especially in the NH. The disagreement between modeled and observed NH lower stratospheric trends may be due partly to the effects of changing dynamics on the ozone fields, which would not be properly represented in a 2D calculation. The residual circulation in the 2D model changes in response to both radiative forcing changes and changes in the planetary wave propagation computed with a planetary wave parameterization. Nevertheless, a zonally averaged model is incapable of moldeling the full three-dimensional dynamics.

\section{Pressure versus Altitude Issues}

Both SBUV and 2D model profiles were in the form of mixing ratios on pressure levels. We have calculated trends for three other representations of the $2 \mathrm{D}$ model ozone profiles; mixing ratios on geometric altitude, number density on pressure, and number density on geometric 
altitude. One can show that in the presence of a temperature trend, the various representations of the profiles will give different ozone trends due to the changing alititudes of pressure surfaces with time and the changing air density on pressure surfaces with time. Between 1979 and 2003 the 2D model temperatures at $3 \mathrm{hPa}$ decreased by 1.4-2.2 K, depending on latitude, as a result of the increasing carbon dioxide.

Figure 5 shows the annual mean 2D model ozone trends at $3 \mathrm{hPa}$ as a function of latitude using the four different coordinate systems for the ozone profiles. Trend differences are as large as 1-2 $\% /$ decade at this altitude, with the largest differences in the southern high latitudes. The most negative trend is computed when ozone profiles are given as number densities on geometric altitude, while the least negative trend is computed for either number densities on pressure or mixing ratios on pressure, depending on latitude. For vertical levels above the ozone partial pressure peak, the computed trends at most latitudes are the most negative when the ozone amount is specified on an altitude coordinate. At vertical levels below the ozone peak, the computed trends are most negative when the ozone amount is specified on a pressure coordinate.

The above example illustrates why care must be taken in comparing SBUV trends with ozone trends from other instruments which use a different vertical coordinate. For example, the SAGE instrument records ozone profiles as number densities on altitude. Thus, Fig. 5 implies that upper stratospheric ozone trends computed from SAGE data will be larger than those computed from SBUV data when the trends are computed in the natural vertical coordinate for each instrument. Typically, SAGE data are converted from number density on altitude to mixing ratio on pressure when comparing to SBUV data [e.g., Wang et al., 1996; McPeters et al., 1994]. A temperature data set is used to carry out this conversion. However, errors in the temperature data can then affect the computed trends. 


\section{Seasonal Trends}

Seasonal and mid-iatitude ( $30^{\circ}$ to $50^{\circ}$ latitude) averages were consirucied for both the SBUV and the 2D model ozone profiles. The four seasons considered were December- JanuaryFebruary (DJF), March-April-May (MAM), June-July-August (JJA), and September-OctoberNovember (SON). The linear regression model (minus the seasonal term) was then applied to each seasonal average.

Season-pressure sections of the computed trends are shown in Figure 6. Winter upper stratospheric negative trends are generally largest and summer negative trends smallest for both observed and modeled ozone, in agreement with previous results [Hood et al., 1993; Hollandsworth et al., 1995; Newchurch et al., 2000]. The fall and spring upper stratospheric trends (not shown) lie in between the winter and summer trends. The model trends, however, do not exhibit as great a seasonal variability as the observed trends. In the NH lower stratosphere, spring trends were most negative and fall trends least negative for both model and observations. In the SH lower stratosphere, observed trends were most negative in the summer (DJF) while model trends were most negative in the spring (SON).

Figure 7 shows profiles of the 2D model and SBUV mid-latitude winter and summer trends. The modeled trends generally agree well with the observed trends above $10 \mathrm{hPa}$. An exception is the SH winter upper stratosphere at $\sim 1-5 \mathrm{hPa}$, where the model trend is less negative than the observed negative trend. Below $10 \mathrm{hPa}$ the 2D model trends greatly underestimate the SBUV negative trends for $\mathrm{NH}$ winter and, to a lesser extent, $\mathrm{SH}$ summer. These disagreements below 10 $\mathrm{hPa}$, particularly in the $\mathrm{NH}$, may be the result of changes in dynamical forcings which are not modeled well by a 2D model. The trends are most negative at $2 \mathrm{hPa}$ in the winter, and 3-4 hPa in the summer. 
Maximum upper stratospheric winter and summer mid-latitude negative trends are given in Table 2. In both hemispheres the winter trend is more downward than the summer trend, although the winter-summer difference is less for the 2D model than for the SBUV data. The model trend is less negative than the observed trend in winter in both hemispheres and is more negative than the observed trend in the $\mathrm{NH}$ summer. As is true for the annual trends, the seasonal winter and summer trends are more negative in the SH than in the $\mathrm{NH}$ for both model and data. Spring and fall trends (not shown) are also more negative in the SH than in the NH for both model and data. Overall, the agreement between observed and modeled upper stratospheric trends is well within the statistical uncertainties.

\section{Discussion}

In this section we explore the reasons for the seasonal and hemispheric differences in the computed upper stratospheric ozone trends. Figure 8 shows the seasonal behavior of $\mathrm{NH}$ and $\mathrm{SH}$ 2D model mid-latitude daytime average $\mathrm{ClO}$ at $2.2 \mathrm{hPa}$ for 1980 and 1992-96. Also shown are the 1992-96 observed daytime ClO values at this altitude from the Microwave Limb Sounder (MLS) instrument on UARS [Randel et al., 1998; http://www.sparc.sunysb.edu]. NH values have been phase shifted by six months in order to better compare the two hemispheres.

The large increase in the model ClO between the years 1980 and 1992-1996 is due to the increasing amounts of CFCs in the stratosphere. The model ClO for the 1992-1996 period is $\sim 20$ $30 \%$ less than the observed $\mathrm{ClO}$, but has the same overall seasonal features. Wintertime and springtime $\mathrm{ClO}$ is greater than summertime $\mathrm{ClO}$ for both model and data. The model and data also show similar hemispheric differences; i.e. greater $\mathrm{ClO}$ in the $\mathrm{SH}$ than the $\mathrm{NH}$, and a greater winter-summer difference in the $\mathrm{SH}$ than the $\mathrm{NH}$. 
Figures 9 and 10 show, for $\mathrm{SH}$ and $\mathrm{NH}$ mid-latitudes, respectively, the model calculated odd oxygen loss frequencies due to the various catalytic cycles as a function of month for the years 1980 and 2000 at $2.2 \mathrm{hPa}$. In 1980 the NOx cycle dominates ozone loss at this altitude. By the year 2000, the chlorine loading of the stratosphere has increased, and ozone loss due to the chlorine catalytic cycle has become dominant in winter and spring (July - November) in the SH. In the $\mathrm{NH}$, although $\mathrm{ClOx}$ loss has greatly increased between 1980 and 2000, the loss due to NOx still predominates. For both hemispheres, NOx loss has increased a small amount, while HOx and Ox losses have decreased. Thus, the increasing importance with time of the ozone loss due to chlorine, together with the greater abundance of $\mathrm{ClO}$ in winter is responsible for the greater computed wintertime ozone trend.

In the upper stratosphere inorganic chlorine exists mainly as $\mathrm{HCl}$ and $\mathrm{ClO}$. The main reactions controlling the partitioning of upper stratospheric chlorine between the active form $\mathrm{ClO}$ and the reservoir $\mathrm{HCl}$ are the following:

$$
\begin{aligned}
& \mathrm{Cl}+\mathrm{O}_{3} \rightarrow \mathrm{ClO}+\mathrm{O}_{2} \\
& \mathrm{ClO}+\mathrm{O} \rightarrow \mathrm{Cl}+\mathrm{O}_{2} \\
& \mathrm{ClO}+\mathrm{NO} \rightarrow \mathrm{Cl}+\mathrm{NO}_{2} \\
& \mathrm{HCl}+\mathrm{OH} \rightarrow \mathrm{Cl}+\mathrm{H}_{2} \mathrm{O} \\
& \mathrm{Cl}+\mathrm{CH}_{4} \rightarrow \mathrm{HCl}+\mathrm{CH}_{3}
\end{aligned}
$$

To a first approximation, the partitioning can be expressed as follows:

$$
\frac{[\mathrm{ClO}]}{[\mathrm{HCl}]} \cong \frac{k_{1}\left[\mathrm{O}_{3}\right]}{k_{2}[\mathrm{O}]+k_{3}[\mathrm{NO}]} \cdot \frac{k_{4}[\mathrm{OH}]}{k_{5}\left[\mathrm{CH}_{4}\right]}
$$

where $\mathrm{k}_{\mathrm{i}}$ is the rate of reaction $\mathrm{i}$. 
Higher concentrations of $\mathrm{O}_{3}$ and $\mathrm{OH}$, and lower concentrations of $\mathrm{O}, \mathrm{NO}$, and $\mathrm{CH}_{4}$ will result in an increase of the $\mathrm{ClO} / \mathrm{HCl}$ ratio. Temperature is also important due to the large temperature dependence of reaction $5\left(\mathrm{k}_{5} \sim \exp [-1360 / \mathrm{T}]\right)$. (The other reactions do not have a significant temperature dependence.) Lower temperatures will thus slow reaction 5 and lead to an increase in reactive chlorine.

We can use model output and observations to address the seasonal and hemispheric differences in $\mathrm{ClO}$ and the derived long-term ozone trends. Figure 11 shows the 1992-1997 average midlatitude seasonal dependence at $2.2 \mathrm{hPa}$ of the model temperatures and the constituents appearing in expression 6. Also shown are observed temperatures, $\mathrm{O}_{3}, \mathrm{NO}$, and $\mathrm{CH}_{4}$. Observed temperatures are from the UKMet Office data set [Swinbank and O'Neill, 1994], observed ozone from the SBUV data used in this study, and observed methane and nitrous oxide from the UARS Reference Atmosphere data set [Randel et al., 1998]. In the mid-latitudes the UARS methane consists of Halogen Occultation Experiment (HALOE) measurements. The UARS NO are also from HALOE observations. HALOE measurements are only for sunrise and sunset conditions. This is not a problem for methane, which is a long lived gas. However, NO has a large diurnal cycle. We show the sunset NO, even though this does not make for an ideal comparison with our daytime average model NO. We are unaware of any other observations of seasonally varying upper stratospheric NO.

According to expression 6, higher $\mathrm{O}_{3}$ and $\mathrm{OH}$ concentrations, and lower $\mathrm{O}, \mathrm{NO}$, and $\mathrm{CH}_{4}$ concentrations in winter would lead to higher $\mathrm{ClO}$ concentrations in winter. Figure 11 shows that the model $\mathrm{O}_{3}, \mathrm{O}$, and $\mathrm{NO}$ exhibit the correct seasonal behavior. In particular, atomic oxygen is approximately a factor of 2 lower in winter. The observed ozone, although greater than the modeled ozone, is also greater in winter than summer with a slightly larger annual cycle in the 
SH than the NH. The observed NO shows a slight tendency to be lower in winter. Neither model $\mathrm{OH}$ nor $\mathrm{CH}_{4}$ show a seasonal behavior that would contribute to higher winter $\mathrm{ClO}$. The UARS $\mathrm{CH}_{4}$ observations, although different than the model $\mathrm{CH}_{4}$, also do not have a seasonal cycle that would lead to higher winter $\mathrm{ClO}$ concentrations.

In Figure 11, the model temperatures have a similar seasonal cycle in both hemispheres, with the temperature in the winter about $15 \mathrm{~K}$ lower than in the summer. The observed temperatures are also lower in winter, but exhibit a much larger seasonal cycle in the SH. Observed SH temperatures are $\sim 25 \mathrm{~K}$ lower in winter than summer, compared to a $\sim 15 \mathrm{~K}$ seasonal difference in the NH.

With respect to the long-term trend in ozone, we noted previously that the model trend is not as negative as the observed trend in the $\mathrm{SH}$, and has a smaller seasonal variation than that derived from SBUV data. The lower winter temperatures contribute to greater winter $\mathrm{ClO}$ concentrations, and thus a larger negative ozone trend in winter, as seen in both observations and model output. The fact that the model SH winter temperatures are $\sim 10 \mathrm{~K}$ warmer than observations likely contributes to the smaller SH winter trend in the model as compared to that derived from SBUV data.

In addition to the seasonal asymmetry in the $\mathrm{ClO}$ concentrations, $\mathrm{ClO}$ also exhibits a hemispheric asymmetry which is reflected in the long-term ozone trend. Both annual and seasonal ozone trends are greater in the $\mathrm{SH}$ than in the $\mathrm{NH}$, as seen in the observations and in the model results. We have seen in Figure 8 that there is a greater abundance of $\mathrm{ClO}$ for most of the year in the $\mathrm{SH}$. Figure 11 shows that model $\mathrm{NO}$ and $\mathrm{CH}_{4}$ are generally less in the $\mathrm{SH}$ than the $\mathrm{NH}$ throughout the year, which would tend towards more $\mathrm{ClO}$ in the $\mathrm{SH}$, and a more negative SH long-term ozone trend. Thus, the modeled hemispheric asymmetries in $\mathrm{NO}$ and $\mathrm{CH}_{4}$ strongly 
support the hemispheric trend asymmetries. The observed $\mathrm{CH}_{4}$ also generally supports the hemispheric asymmetry in $\mathrm{ClO}$ seen in the model, with methane concentrations in nine of the twelve months being lower in the SH. The observed NO is less in the SH than the NH in late summer and spring, but not at other times of the year. However, as discussed previously, the observed sunset NO may not be a good surrogate for daytime average NO. Thus, the observed hemispheric asymmetries in $\mathrm{CH}_{4}$, and less so $\mathrm{NO}$, generally support the observed trend asymmetries.

\section{Summary}

Ozone profile trends have been derived from the new Version 8 SBUV data and from the GSFC 2D interactive model. The general pattern of maximum negative annual trends in the higher latitude upper stratosphere and lower stratosphere, with minimum negative trends in between, is in agreement with previous results. Upper stratospheric SH trends are more negative than NH trends. In the mid-latitudes, the most negative annual upper stratospheric SBUV SH trend is $-4.6 \pm 0.6 \%$ decade, compared with $-3.4 \pm 0.6 \% /$ decade in the NH. Model maximum negative mid-latitude trends are $-3.8 \pm 0.3 \%$ /decade and $-3.6 \pm 0.2 \%$ /decade in the SH and NH, respectively.

Annual trends were compared for four different coordinate representations of the model ozone: mixing ratio on altitude, mixing ratio on pressure, number density on altitude, and number density on pressure. These trends all differ as a result of the temperature trend occurring during the time period. The ordering of the trend magnitudes at a given altitude depends on whether that altitude is above or below the ozone peak (in partial pressure). In the upper stratosphere, number density on altitude gave the most negative trend, with the other coordinate representations giving trends $1-2 \% /$ decade less negative depending on latitude. 
Seasonal trends in the mid-latitudes were computed using the SBUV ozone data and the 2D model ozone profiles. Winter trends were found to be the most negative and summer trends the least negative in both hemispheres, with seasonal trends more negative in the $\mathrm{SH}$ than the $\mathrm{NH}$ for both model and data. The more downward winter trends were shown to result from the greater abundance of $\mathrm{ClO}$ in the winter and the increasing importance with time of the ozone loss due to the chlorine catalytic cycle. The more negative SH annual and seasonal trends were shown to result from the greater amount of $\mathrm{ClO}$ in the $\mathrm{SH}$, due mainly to less $\mathrm{CH}_{4}$ in the $\mathrm{SH}$. The agreement between modeled and observed upper stratospheric trends is well within the statistical uncertainties. 


\section{References}

Chandra, S., C.H. Jackmañ, and E.L. Fleming, Recent trends in ozone in the upper stratosphere: Implications for chlorine chemistry, Geophys. Res. Lett., 22, 843-846, 1995.

Considine, D.B., A.E. Dessler, C.H. Jackman, J.E. Rosenfield, P.E. Meade, M.R. Schoeberl, A.E. Roche, and J.W. Waters, Interhemispheric asymmetry in the $1 \mathrm{mbar} \mathrm{O} 3$ trend: An analysis using an interactive zonal mean model and UARS data, J. Geophys. Res., 103(D1), 1607-1618, 1998.

Considine, D.B., J.E. Rosenfield, and E.L. Fleming, An interactive model study of the influence of the Mount Pinatubo aerosol on stratospheric methane and water trends, J. Geophys. Res., $106(D 21), 27,711-27,727,2001$.

Cunnold, D.M., M.J. Newchurch, L.E. Flynn, H.J. Wang, J.M. Russell, R. McPeters, J.M.

Zawodny, and L. Froidevaux, Uncertainties in upper stratospheric ozone trends from 1979-1996, J. Geophys. Res., 105(D4), 4427-4444, 2000.

Hollandsworth, S.M., R.D. McPeters, L.E. Flynn, W. Planet, A.J. Miller, and S. Chandra, Ozone trends deduced from combined Nimbus 7 SBUV and NOAA 11 SBUV/2 data, Geophys. Res. Lett., 22, 905-908, 1995. 
Hood, L.L., R.D. McPeters, J.P. McCormack, L.E. Flynn, S.M. Hollandsworth, and J.F. Gleason, Altitude dependence of stratospheric ozone tuends based on Ninbus 7 SBUV data, Geophys. Res. Lett., 20(D23), 2667-2670, 1993.

Jackman, C.H., E.L. Fleming, S. Chandra, D.B. Considine, and J.E. Rosenfield, Past, present, and future modeled ozone trends with comparisons to observed trends, J. Geophys. Res., 101(D22), 28,753-28,767, 1996.

Li, J., D.M. Cunnold, H-J. Wang, E.-S. Yang, and M.J. Newchurch, A discussion of upper stratospheric ozone asymmetries and SAGE trends, J. Geophys. Res., 107(D23), 4705, doi:10.1029/2001JD001398, 2002.

McPeters, R.D., T. Miles, L.E. Flynn, C.G. Wellemeyer, and J.M. Zawodny, Comparison of SBUV and SAGE II ozone profiles: Implications for ozone trends, J. Geophys. Res., 99(D10), 20,513-20,524, 1994.

Newchurch, M.J., et al., Upper-stratospheric ozone trends 1979-1998, J. Geophys. Res., 105(D11), 14,625-14,636, 2000.

Randel, W.J., F. Wu, J.M. Russell III, A. Roche, and J. Waters, Seasonal cycles and QBO variations in stratospheric CH4 and $\mathrm{H} 2 \mathrm{O}$ observed in UARS HALOE data, J. Atmos. Sci., 55, 163-185, 1998. 
Randel, W.J., R.S. Stolarski, D.M. Cunnold, J.A. Logan, M.J. Newchurch, and J.M. Zawodny, Trends in the vertical distribution of ozonc, Science, 285, 1689-1692, 1999.

Rosenfield, J.E., D.B. Considine, P.E. Meade, J.T. Bacmeister, C.H. Jackman, and M.R. Schoeberl, Stratospheric effects of Mount Pinatubo aerosol studied with a coupoled twodimensional model, J. Geophys. Res., 102 (D3), 3649-3670, 1997.

Rosenfield, J.E., Effects of volcanic eruptions on stratospheric ozone recovery, in Volcanism and the Earth's Atmosphere, Geophys. Monogr. Series, vol. 139, edited by A. Robock and C. Oppenheimer, pp. 227-236, AGU, Washington, D.C., 2003.

Rosenfield, J. E., A. R. Douglass, and D. B. Considine, The impact of increasing carbon dioxide on ozone recovery, J. Geophys. Res., 107, (D6), 10.1029/2001JD000824, 2002.

Sander, S. P., et al., Chemical kinetics and photochemical data for use in stratospheric modeling, Evaluation number 14, JPL Publ. 02-25, 334 pp., 2003.

Solomon, S., Stratospheric ozone depletion: A review of concepts and history, Rev. Geophys., $37(3), 275-316$.

Swinbank, R. and A. O'Neill, A stratosphere-troposphere data assimilation system, Mon. Weather Rev., 122, 686-702, 1994. 
Wang, H.J., D.M. Cunnold, and X. Bao, A critical analysis of Stratospheric Aerosol and Gas Experiment ozonc trends, J. Geophys. Res., 101, 12,495-12,514, 1996.

World Meteorological Organization (WMO), Scientific assessment of ozone depletion: 1991, Global Ozone Research and Monitoring Project-Report No. 25, Geneva, 1991.

World Meteorological Organization (WMO), Assessment of Trends in the Vertical Distribution of Ozone, Stratospheric Processes and their Role in Climate (SPARC) Report 1, Global Ozone Research and Monitoring Project-Report No.43, Geneva, 1998.

World Meteorological Organization (WMO), Scientific assessment of ozone depletion: 1998, Global Ozone Research and Monitoring Project-Report No. 44, Geneva, 1999.

World Meteorological Organization (WMO), Scientific assessment of ozone depletion: 2002, Global Ozone Research and Monitoring Project-Report No. 47, Geneva, 2003. 


\section{Figure Captions}

Figure 1. Latitude-pressure sections of SBUV annual mean ozone trends in \%/decade. Shaded areas are not significant at the $2 \sigma$ level.

Figure 2. Latitude-pressure sections of 2D model annual mean ozone trends in \%/decade. Shaded areas are not significant at the $2 \sigma$ level.

Figure 3. Same as Fig. 2 except for case when $\mathrm{CO}_{2}$ values were fixed at 1979 amounts.

Figure 4. Profiles of SBUV and 2D model annual mean ozone trends in \%/decade, for northern hemisphere mid-latitudes (left) and southern hemisphere mid-latitudes (right). The error bars show the $1 \sigma$ statistical uncertainties of the SBUV trend fits.

Figure 5. 2D model annual mean ozone trend at $2.2 \mathrm{mb}$ in \%/decade as a function of latitude. The blue curve refers to ozone number density on pressure levels, the red curve to ozone mixing ratios on pressure levels, the green curve to ozone mixing ratios on geometric altitude levels, and the fuschia curve to ozone number densities

Figure 6. Season-pressure sections of SBUV and 2D model mid-latitude ozone trends in $\% /$ decade. Top (bottom) figures are for the northern (southern) hemispheres. 
Figure 7. Profiles of SBUV and 2D model winter and summer mid-latitude ozone trends in $\% /$ decade. The error bars show the $1 \sigma$ statistical uncertainties of the SBUV irend fits.

Figure 8. Mid-latitude $\left(30^{\circ}-50^{\circ}\right) \mathrm{ClO}$ at $2.2 \mathrm{hPa}$ as a function of month for the $\mathrm{SH}$ (solid lines) and NH (dashed lines). The NH values have been phase shifted by 6 months. The red (blue) curves are the 1980 (1992-1996) 2D model results, and the green curves are the 1992-1996 UARS MLS data.

Figure 9. SH mid-latitude odd oxygen loss frequencies at $2.2 \mathrm{hPa}$ from the 2D model. Solid lines refer to the year 2000 and dashed lines to the year 1980. The loss cycles are ClOx (red), NOx (blue), HOx (green), and Ox (fuschia).

Figure 10. Same as Figure 9, except for the NH. The NH values have been phase shifted by 6 months.

Figure 11. Seasonal dependence of average 1992-1997 temperature and constituents at $2.2 \mathrm{hPa}$ and $30^{\circ}-50^{\circ}$ latitude. The solid line represents the $\mathrm{SH}$ and the dashed line represents the NH. NH values are shifted by six months. Black curves are the 2D model results, while red curves are observations. The UKMet temperatures were interpolated to $2.2 \mathrm{hPa}$. The UARS methane is from the UARS Reference Atmosphere Project, and consists of HALOE data. The UARS NO is HALOE sunset data. 
Table 1. Maximum upper stratospheric annual trends at $47.5^{\circ}$ in $\% /$ decade

\begin{tabular}{llc}
\hline & $\mathrm{NH}$ & $\mathrm{SH}$ \\
\hline SBUV & $-3.8(0.5)$ & $-5.5(0.9)$ \\
2D Model & $-4.0(0.2)$ & $-4.5(0.3)$ \\
2D Model & $-5.0(0.2)$ & $-5.5(0.3)$ \\
(fixed $\left.\mathrm{CO}_{2}\right)$ & & \\
\hline ( ) 10 statistical error &
\end{tabular}


Table 2. Maximum upper stratospheric mid-latitude seasonal trends in \%/decade

\begin{tabular}{lcccc}
\hline & NH Winter & NH Summer & SH Winter & SH Summer \\
\hline SBUV & $-4.8(1.6)$ & $-2.5(0.9)$ & $-5.7(1.4)$ & $-3.9(0.9)$ \\
2D Model & $-4.0(0.8)$ & $-3.5(0.8)$ & $-4.4(0.9)$ & $-3.8(0.7)$ \\
\hline () 10 statistical error & & &
\end{tabular}




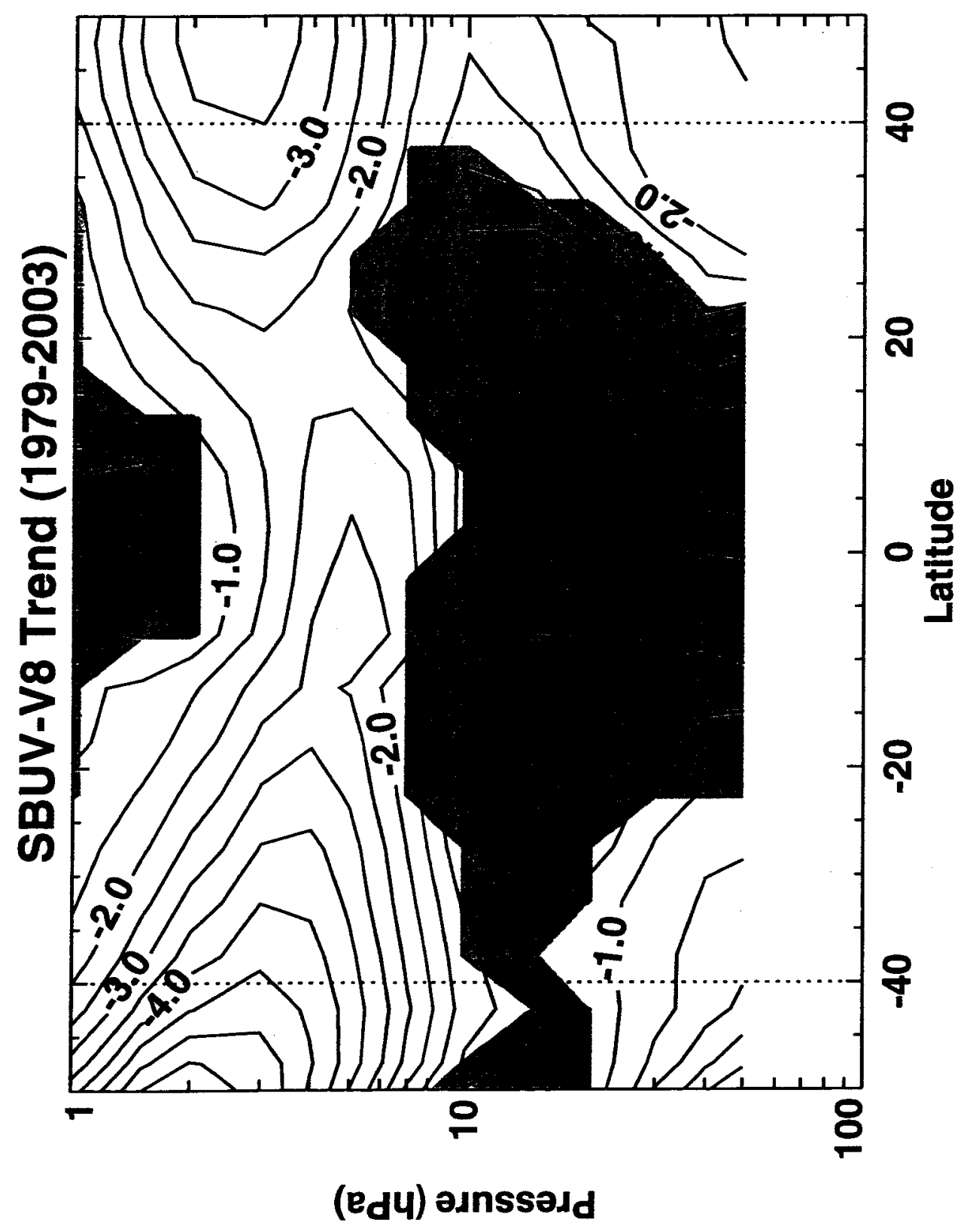




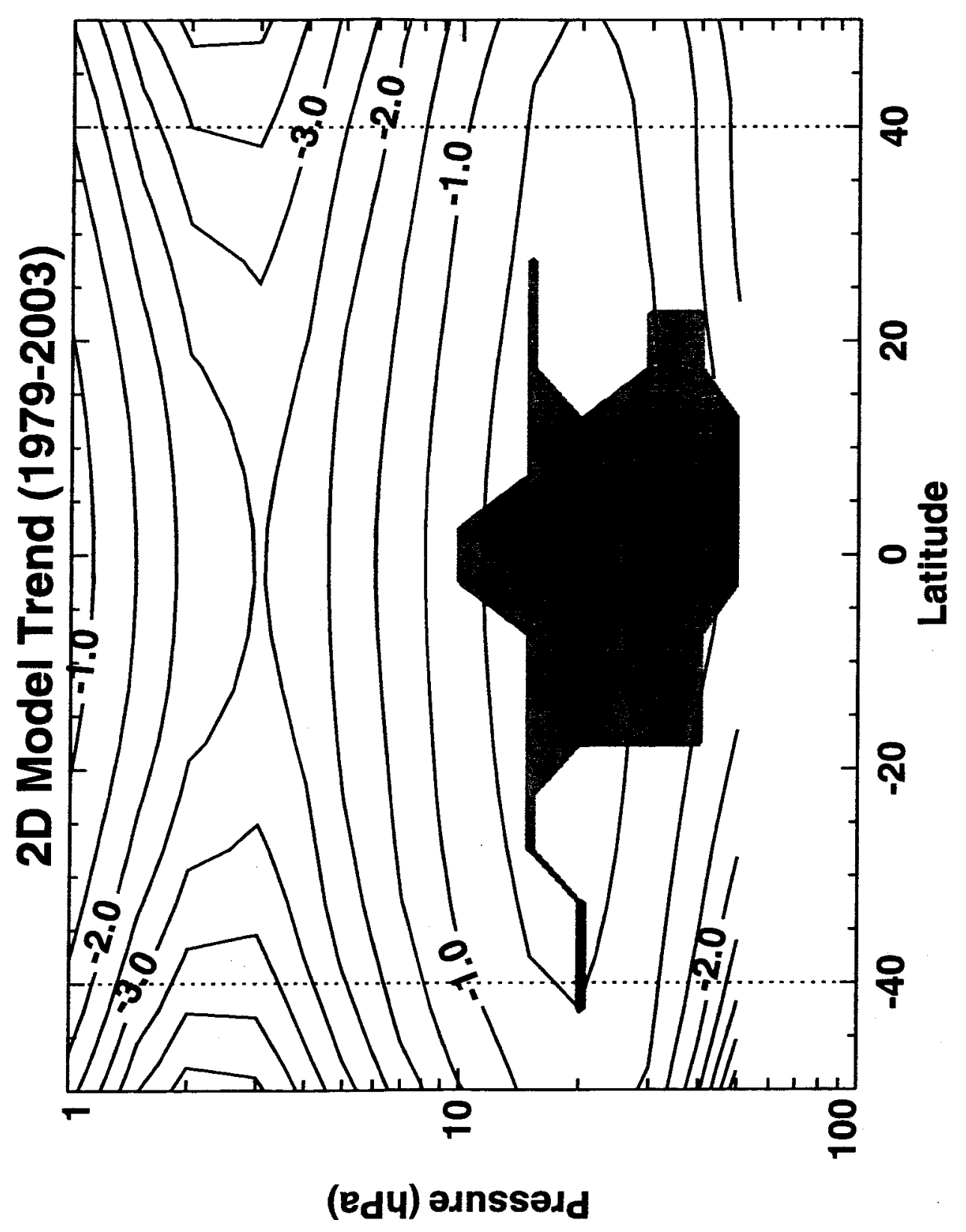




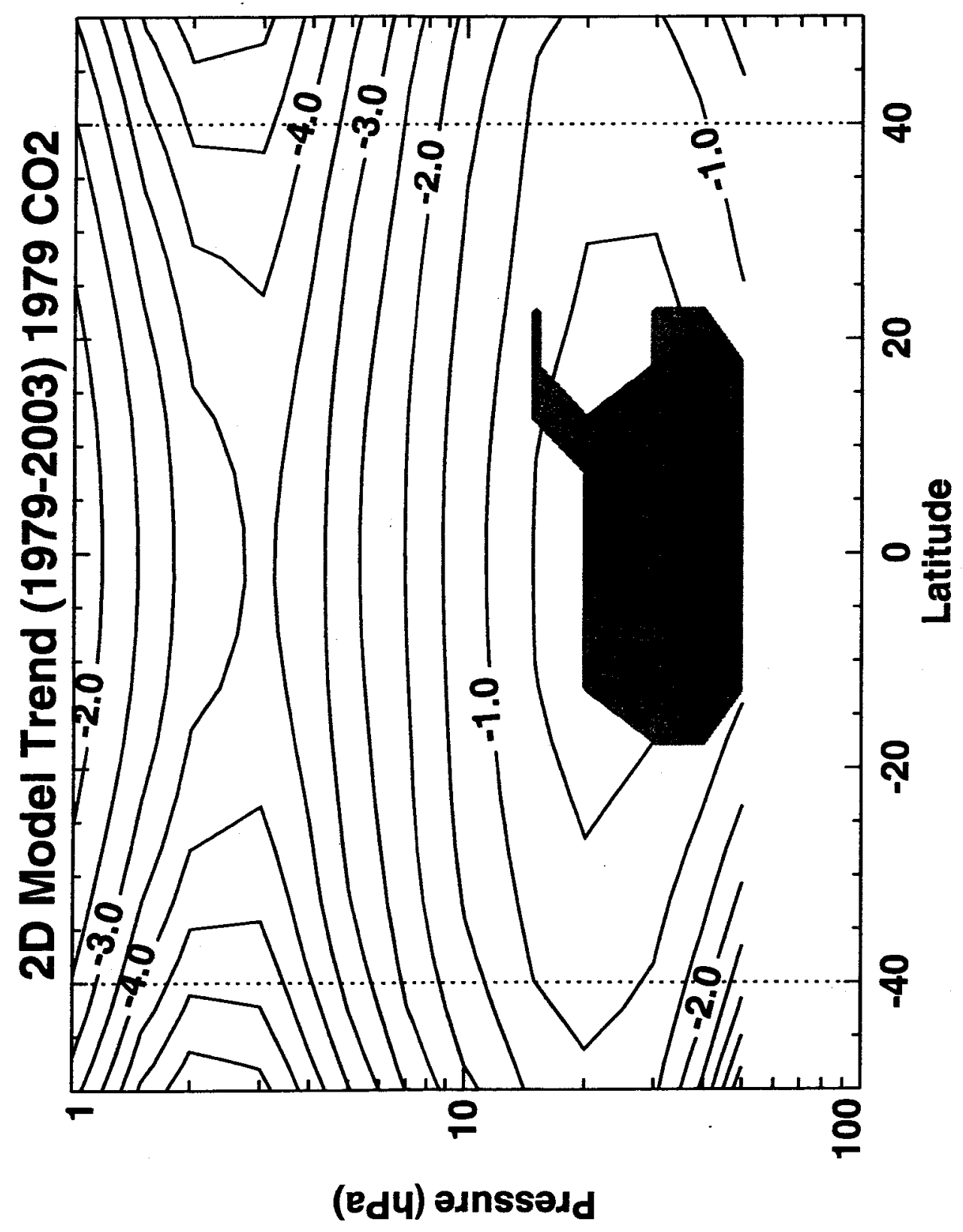


$\sqrt{ }$

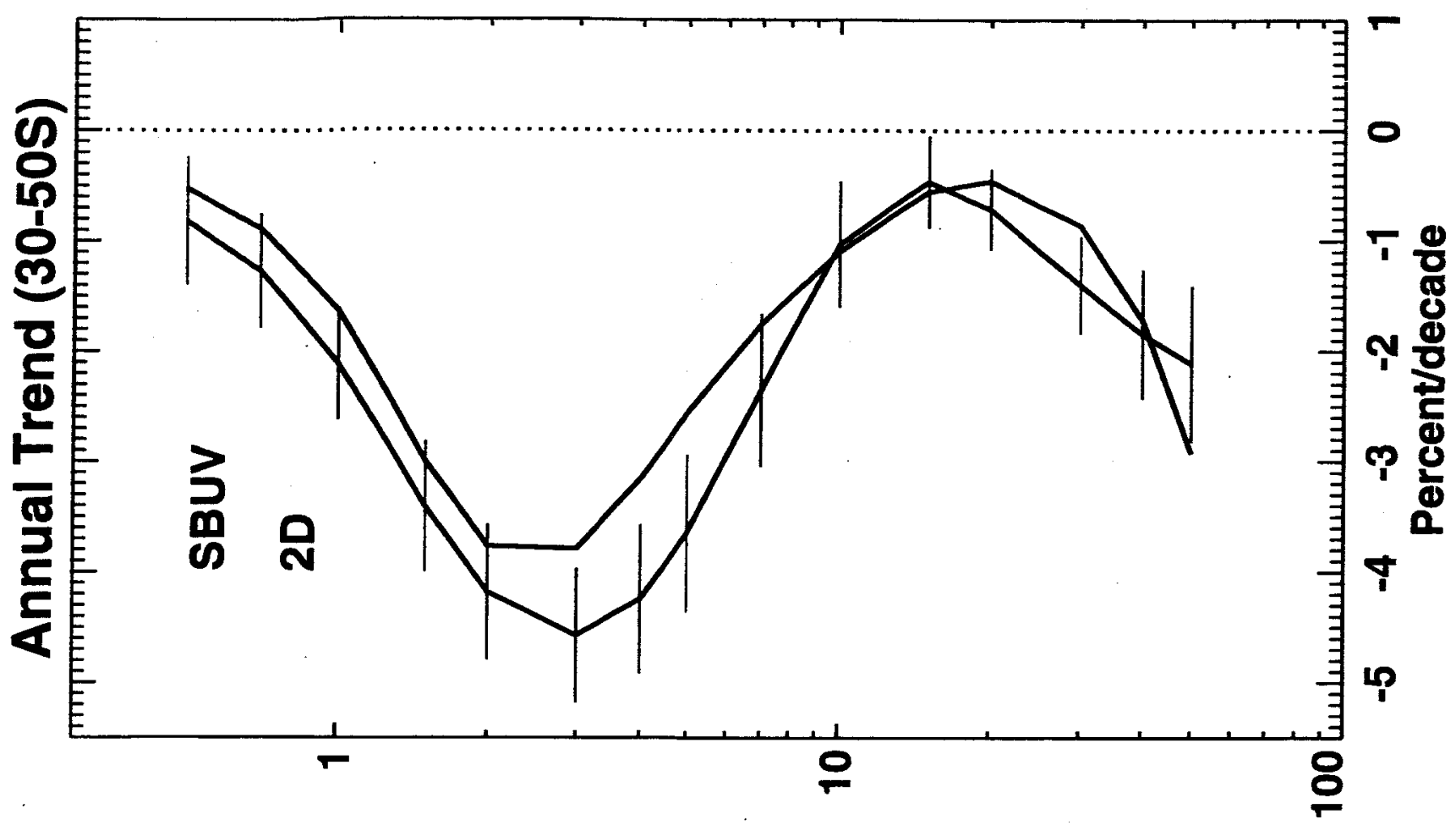

(edy) odnssadd

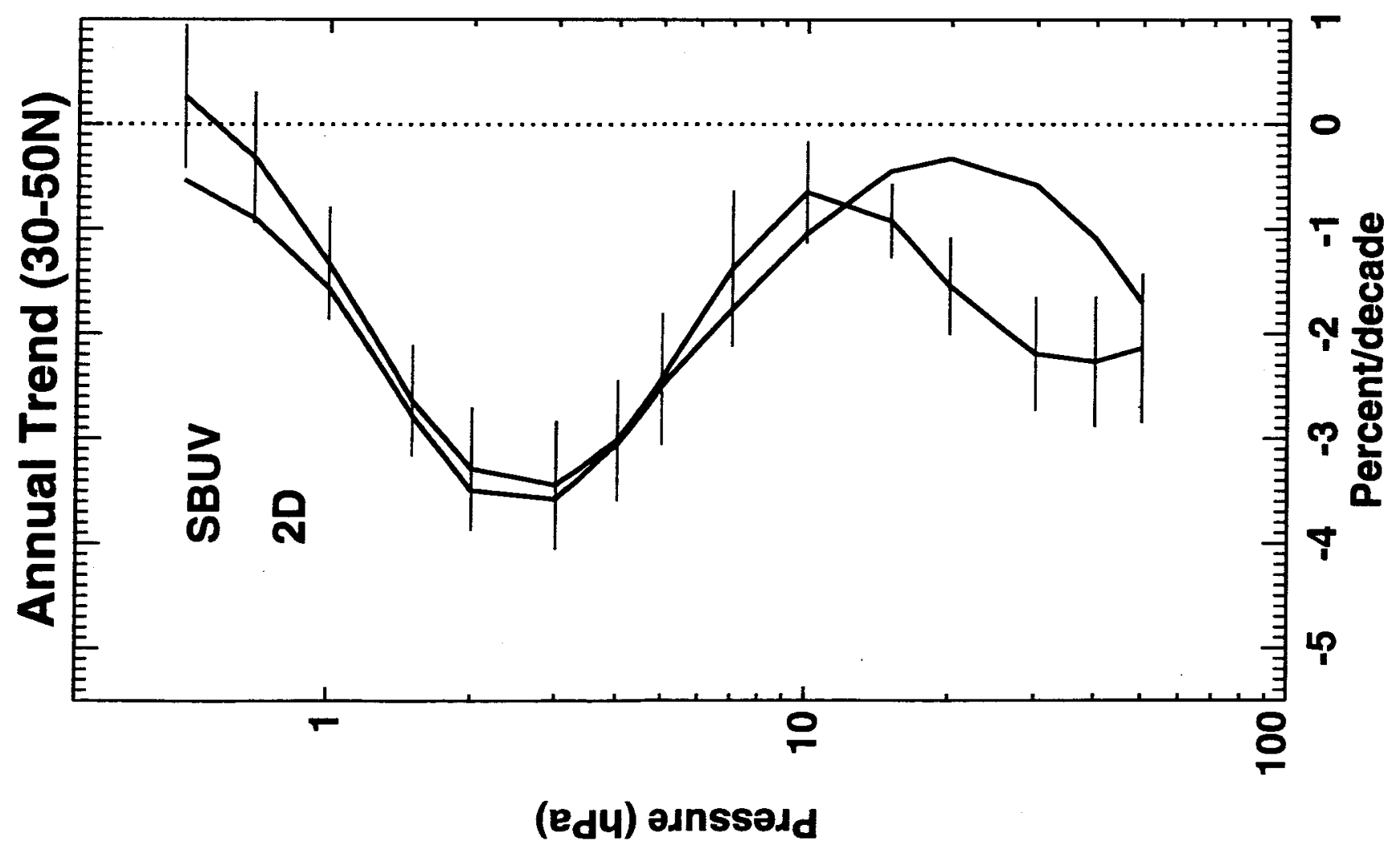




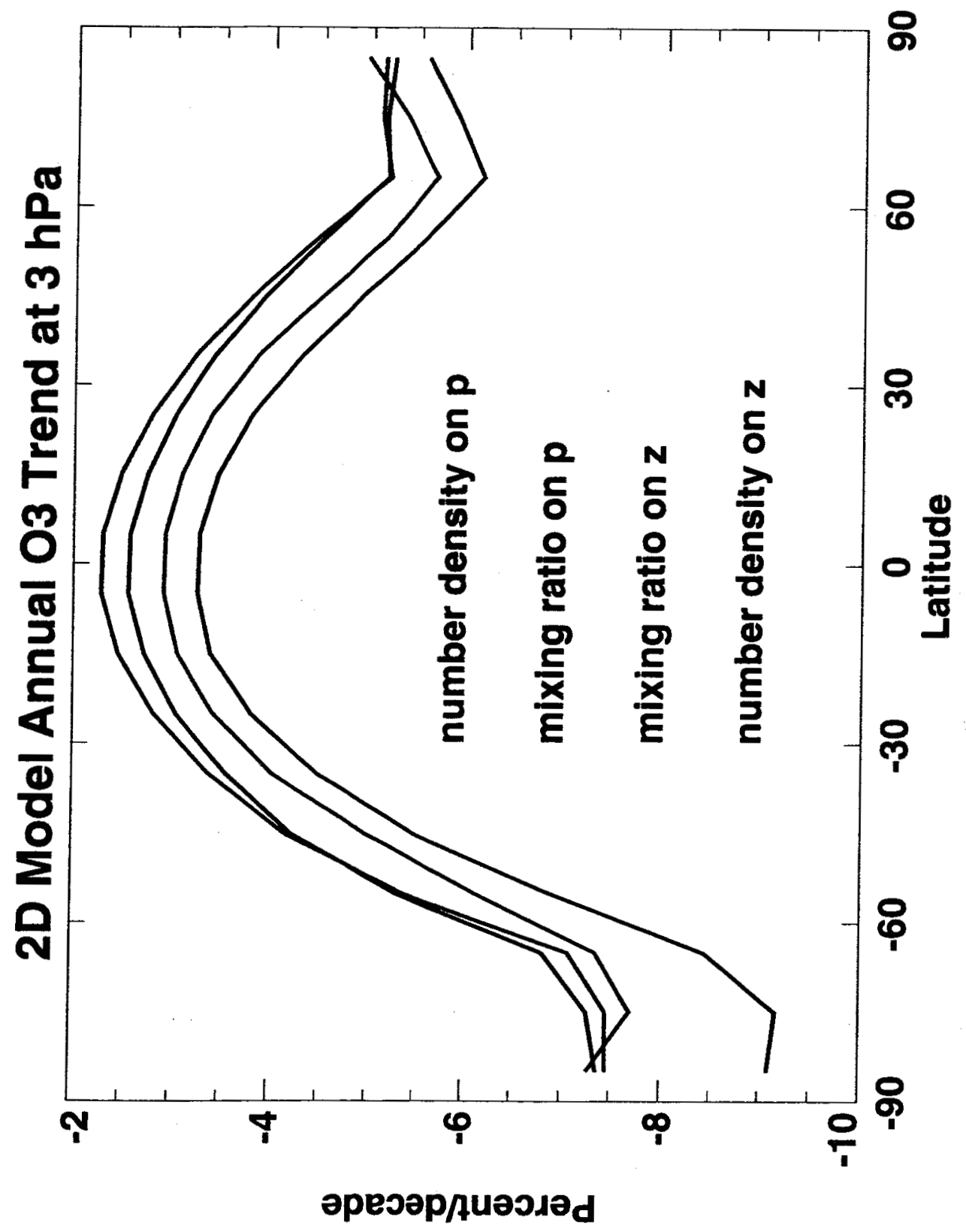



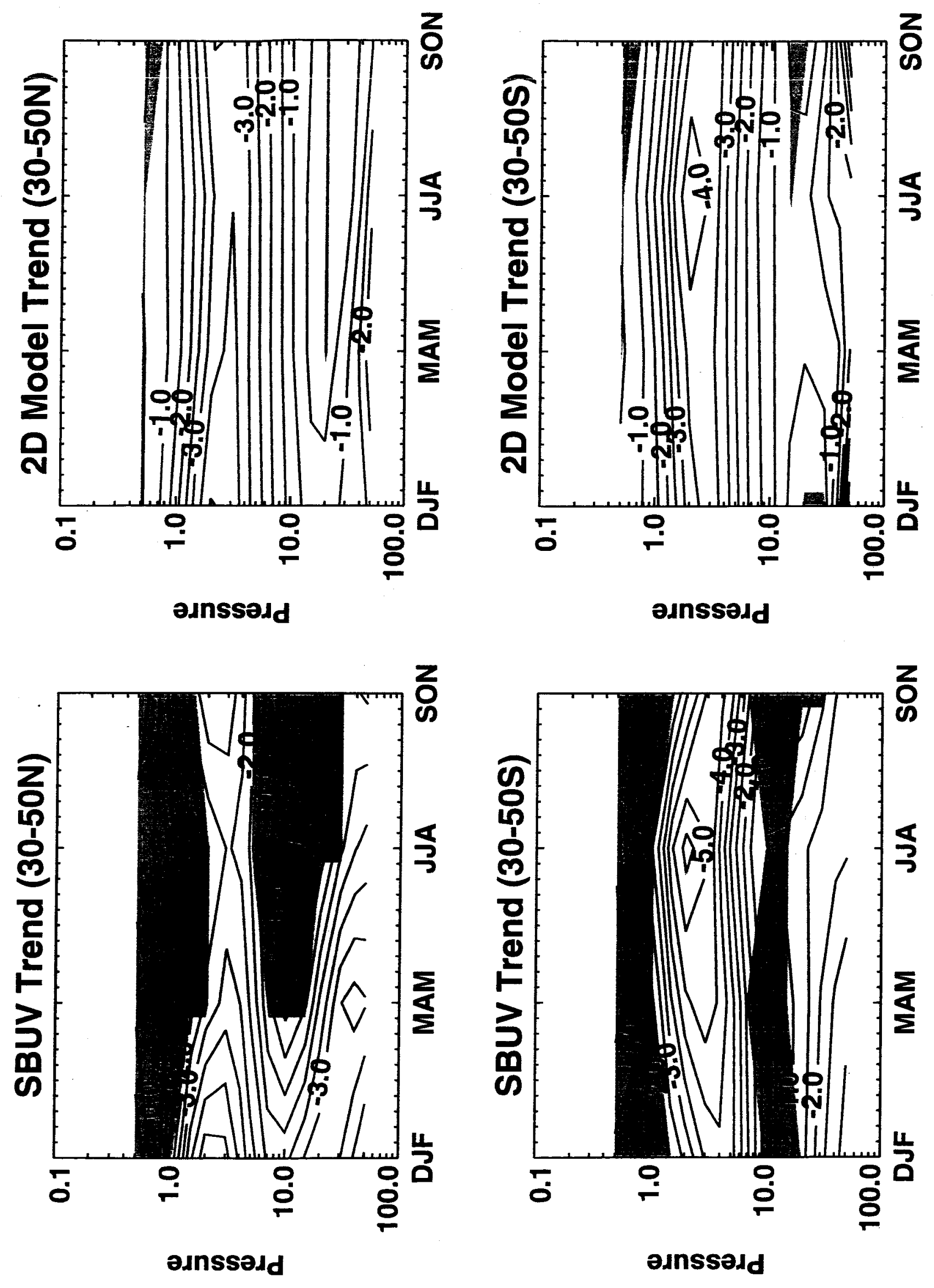


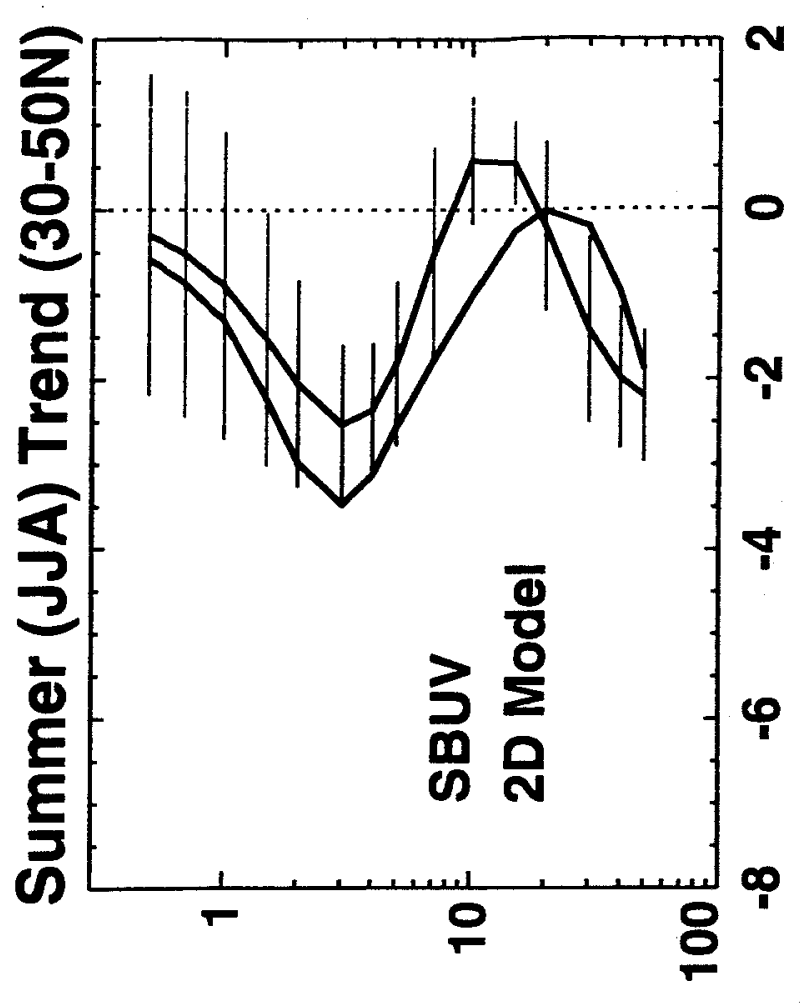

(ed4) adnssadd

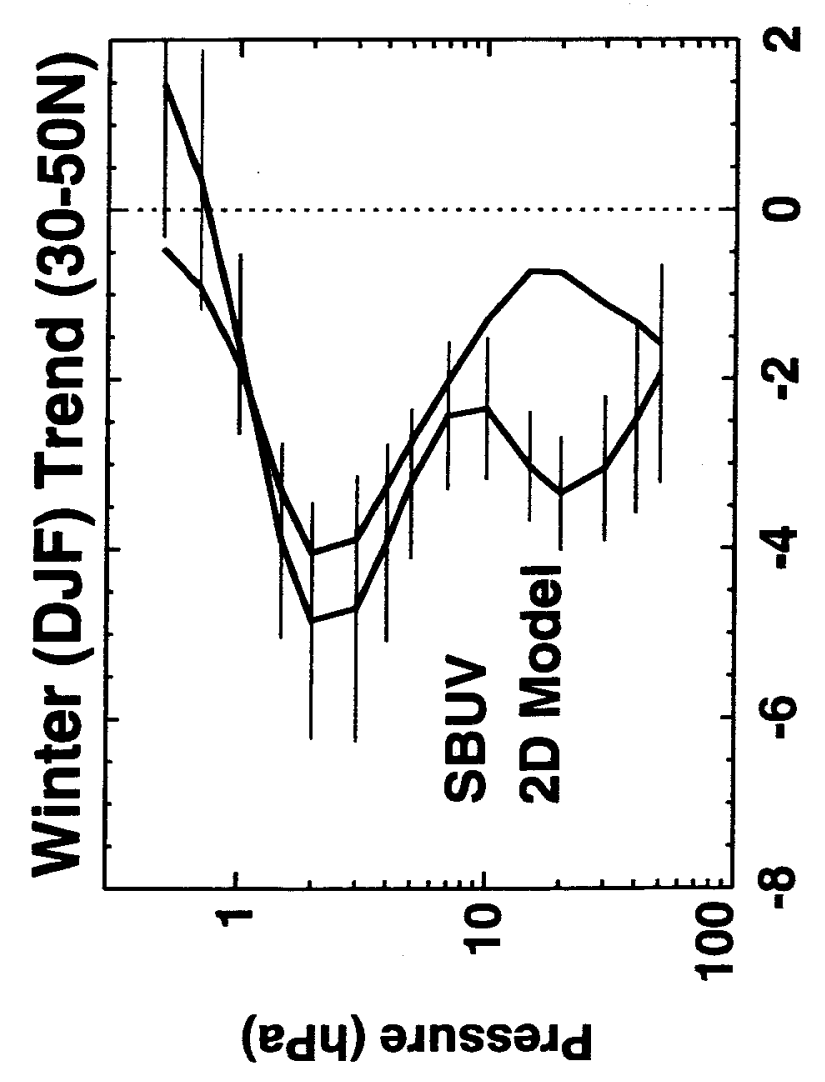

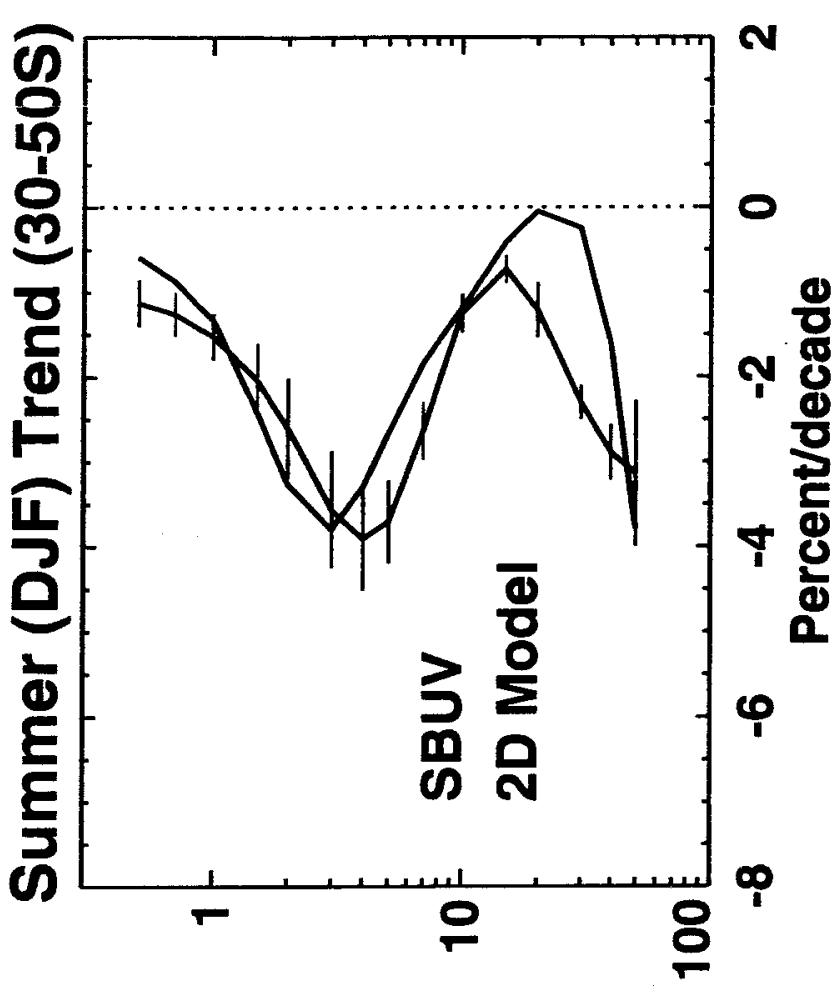

(ed4) odnssadd

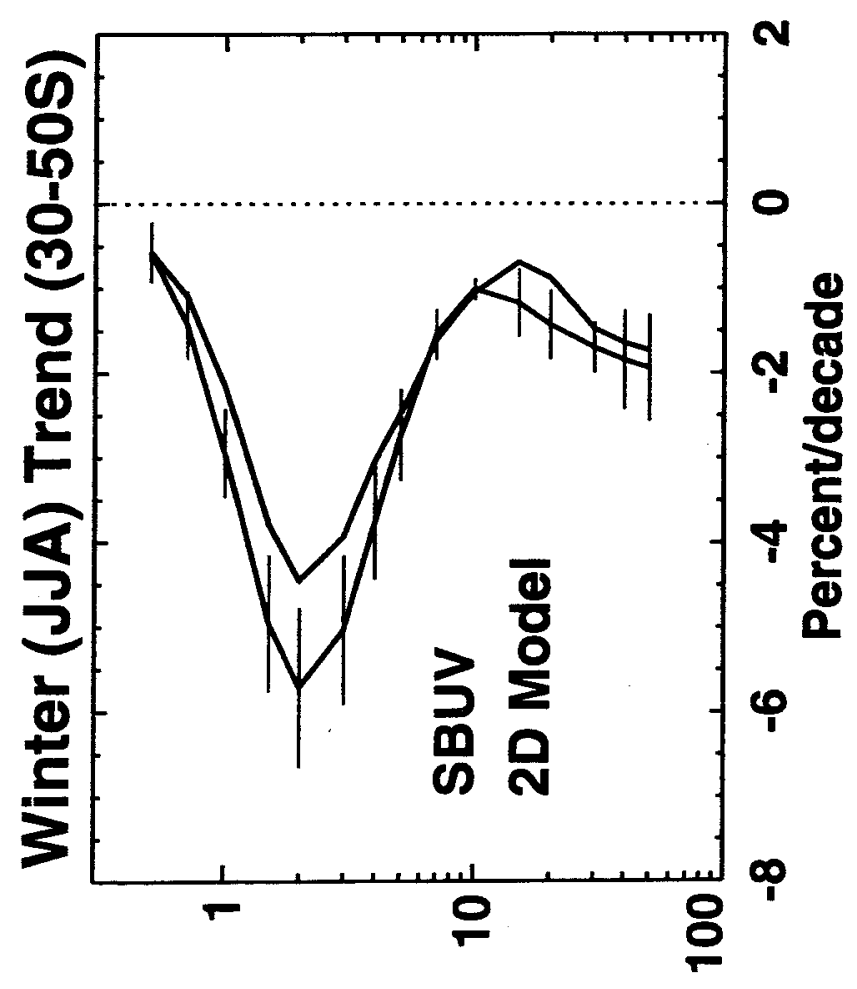

(ed4) o.nssedd 
$\infty$

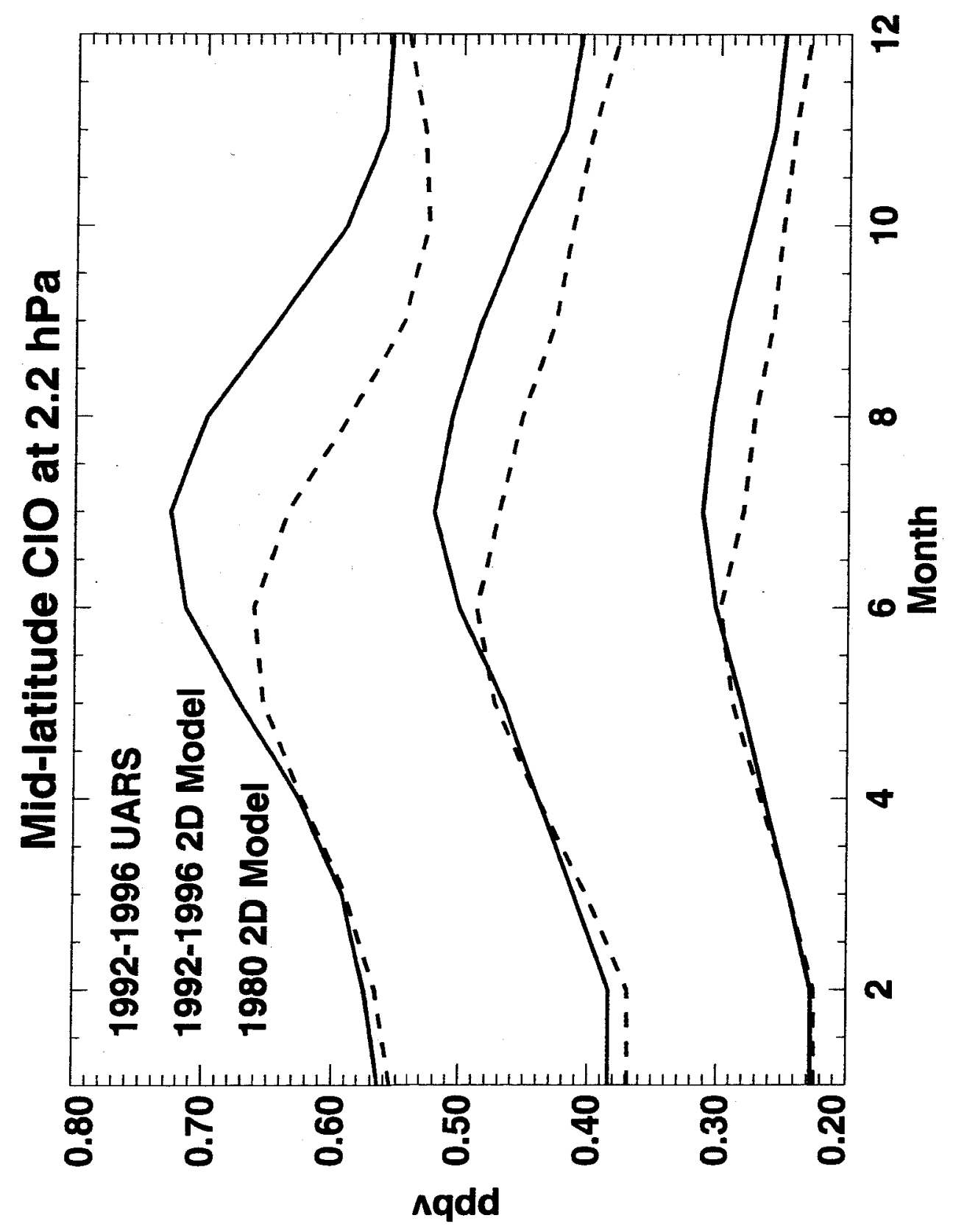




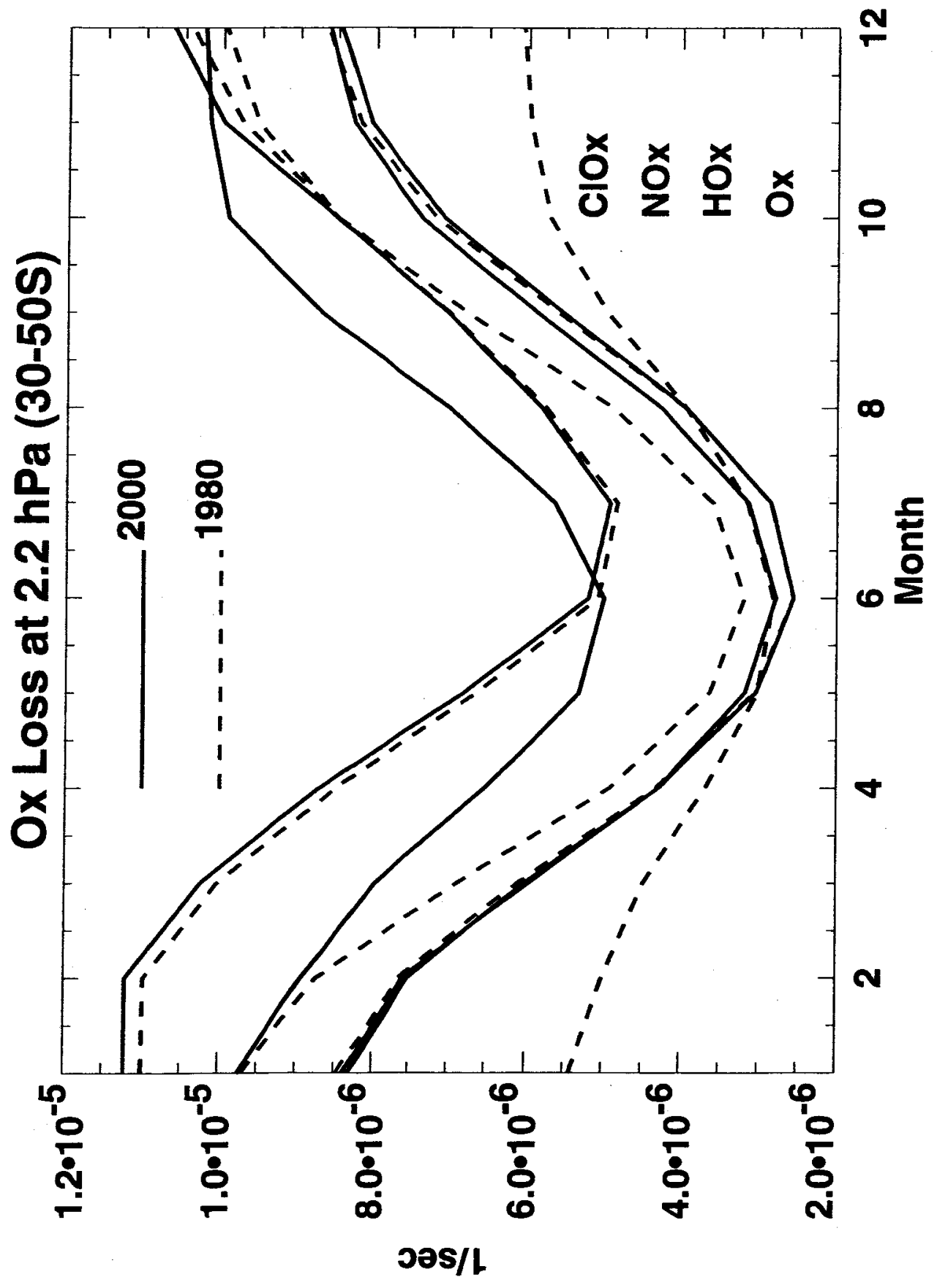




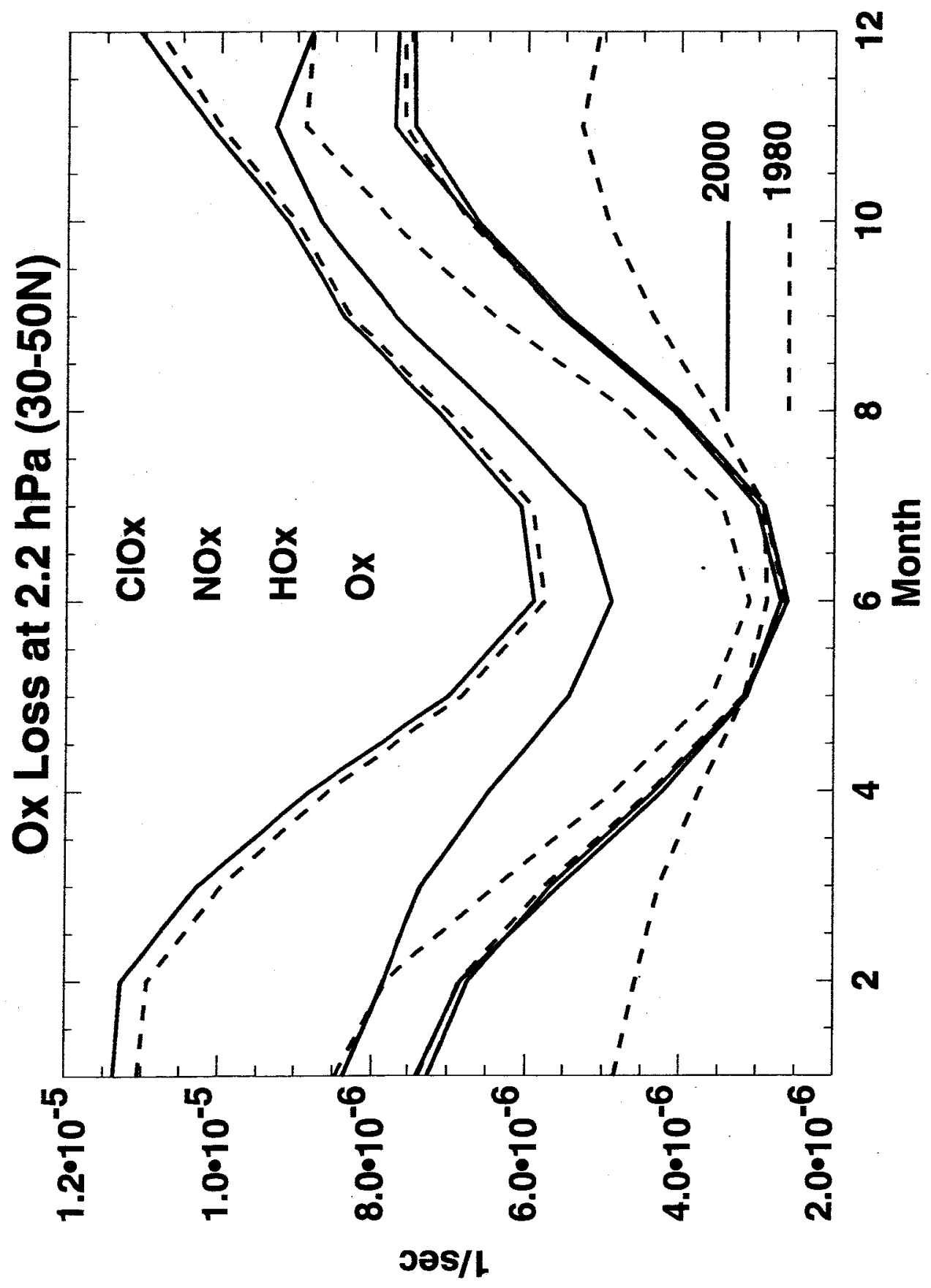



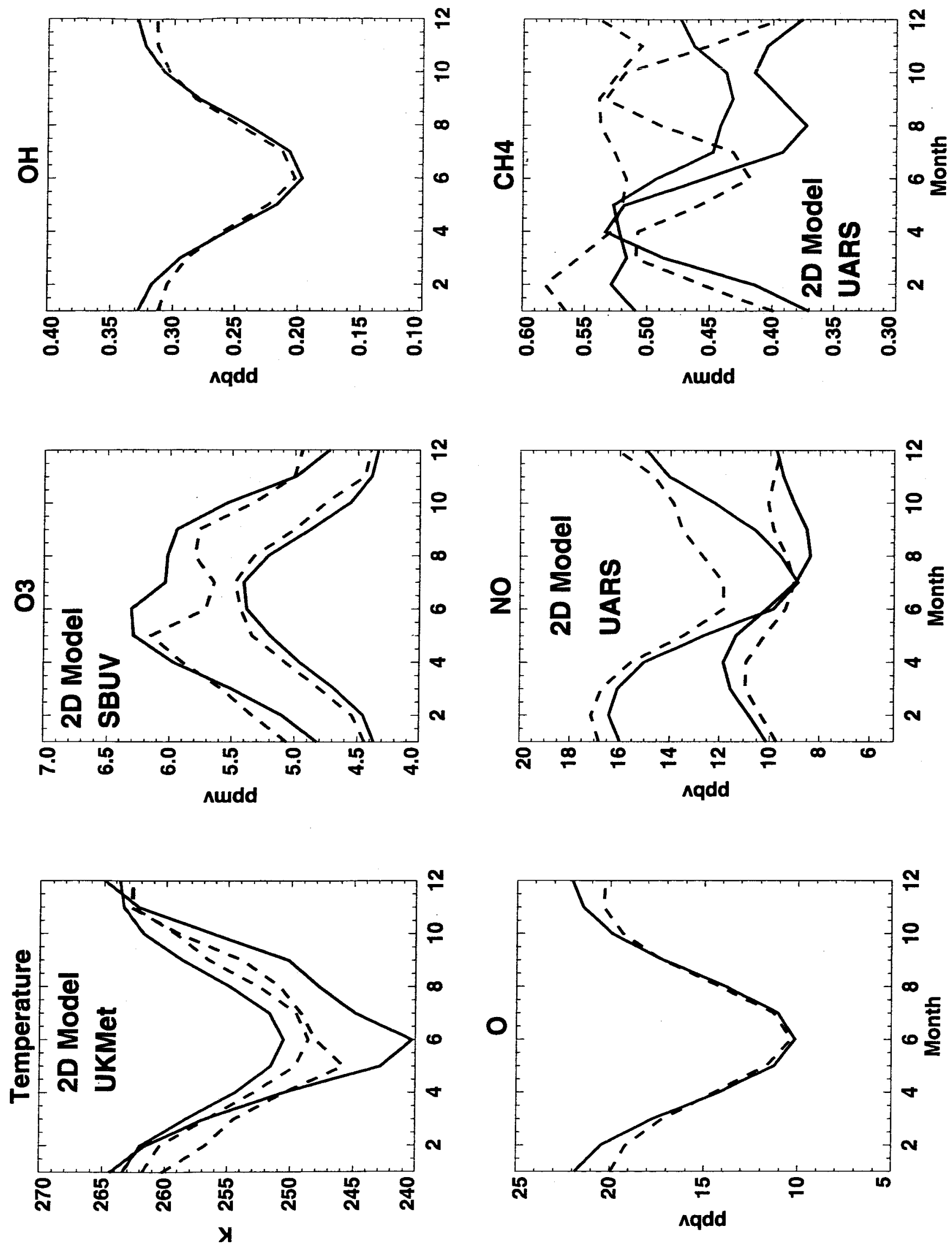
Popular Summary

"Version \& SBUV Ozone Profile Trends Compared with Trends from a Zonally Averaged Chemical Model", J. E. Rosenfield, S. Frith, and R. Stolarski

It is well documented that negative trends in stratospheric ozone have arisen from the increasing amounts of anthropogenic chlorofluorocarbons (CFCs) released into the atmosphere. In this work we compute linear trends in ozone for the years 1979-2003 using the new Version 8 merged Solar Backscatter Ultraviolet (SBUV) data set of ozone vertical profiles. These trends are compared to trends computed using output from the Goddard Space Flight Center interactive 2D (latitude-pressure) model. Both observed and modeled annual trends are a maximum in the higher latitudes of the upper stratosphere, with southern hemisphere trends more negative than northern hemisphere trends, and winter trends more negative than summer trends. Overall, the agreement between observed and modeled upper stratospheric trends is well within the statistical uncertainties. This agreement of modeled and observed trends lends credence to the model predictions of future changes in upper stratospheric ozone.

SBUV vertical profiles are given in the form of mixing ratios on pressure levels. We have calculated trends for four different coordinate representations of the model ozone: mixing ratio on altitude, mixing ratio on pressure, number density on altitude, and number density on pressure. These trends all differ as a result of the temperature trend occurring during the time period. Thus care must be taken in comparing SBUV trends with ozone trends from other instruments which use a different vertical coordinate. 